Available Online at http://journal.unismuh.ac.id/index.php/otoritas

Otoritas : Jurnal Ilmu Pemerintahan, 8 (1), April 2018, 17-31

\title{
Discretion and Decentralization: Public Administrators Dilemmas in Bureaucracy Innovation Initiatives
}

\author{
Lesmana Rian Andhika*) \\ Department of Public Administration, Faculty of Social and Political Sciences, \\ Universitas Padjadjaran, Jln. Raya Bandung Sumedang, Jatinangor 45363, Jawa Barat, Indonesia.
}

Received: 31 December 2017; Revised: 20 January 2018; Accepted: 9 February 2018

\begin{abstract}
Policy discretion shall not be construed as a free authority by the public administrator. The positive side discretion is answered to an urgent need, the ambiguity caused the existing policy. The focus this researched would like to explore further the public administrator dilemmas perform some correlation between policy discretion and decentralization, discretion and initiation of bureaucracy innovation. The research method applied is qualitative, descriptive analysis is adopted based on secondary data and information sources. Triangulation is used to draw conclusions carefully from a variety of data sources. The research concludes the initiation of bureaucracy innovation is the urgent needs at this time, and discretion one of the tools that can be used as a policy outside the formal policy not set explicitly on the different the element related with innovation. The unique thing is not all public administrators like and can do discretion, there is a logical consideration that must be met to assess and translate discretion, capability and sufficient knowledge is some logical considerations it is. Bias interpretation will cause negative effects like opening a chance doing the corruption, collusion, nepotism and the occurrence of criminalization policy procedures.
\end{abstract}

Keywords: Discretion; Public Administrator Dilemmas; Bureaucracy Innovation

How to Cite: Andhika, L. R. (2018). Discretion and Decentralization: Public Administrators Dilemmas in Bureaucracy Innovation Initiatives. Otoritas : Jurnal Ilmu Pemerintahan, $8(1), 17-31$.

Permalink/DOI: https://doi.org/10.26618/ojip.v8i1.1040

${ }^{*}$ Corresponding Author.

E-Mail : lesmana15001@mail.unpad.ac.id

Copyright (C) 2018, Otoritas : Jurnal Ilmu Pemerintahan, ISSN: 2088-3706 (Print), ISSN: 2502-9320 (Online) 
Available Online at http://journal.unismuh.ac.id/index.php/otoritas

Otoritas : Jurnal Ilmu Pemerintahan, 8 (1), April, 2018, 18

\section{INTRODUCTION}

Decentralization currently undergoing development with a different study, a definition of decentralization began emerging with a different phrase such as asymmetrical decentralization, and devolution decentralization, (Cheema \& Rondinelli, 2007; Parry, 2008; Dubois \& Fattore, 2009; Amrizal et al., 2015). Although some scholars argue that decentralization is already contained such specificity, but various local wisdom will force settings that do not refer to one policy and decentralization may also policy affect. The vast powers that be early for the local government to organize and attempt to resolve any problems that occur. The problems in popular government activities are referred to as the bureaucracy pathology. A wide variety of initiation into the objective needs to be able to look for patterns and ways that are considered new to solve the problem. Under certain conditions, it can be done discretion. Due to higher rules often do not provide clues about a range of systematic activities to it. To do technically necessary discretion of policy derivate, and policy can be made to look for ways that are new considered (Galavan, Murray, \& Markides, 2008; Sahaym, Trevino, \& Steensma, 2012), this new way is considered often associated with innovation in bureaucracy (Borins, 2008; Torfing \& Triantafillou, 2016; McLaughlin \& Kennedy, 2016).

Public administrator dilemmas to conduct policy discretion with the aim to provide good public service to a citizen is not necessarily that activity be good, even the public administrator will cause perceived abuse of power and authority. Then the hope began to appear with the enactment of Law Republic of Indonesia Number 30/2014 on Government Administration. This law for any public administrator to conduct policy discretion. In general, the government officials understand discretion as an authority (friesermessen) and authorities were also understood his own opinion (Prasojo, 2014). Interpretation of biased about discretion raises a variety of negative consequences such as problems of corruption within the bureaucracy. Policy discretion initially was exploited by unscrupulous officials to take decisions, and tend to be discretion made to acts of corruption. A common practice is done by managing the budget without the rules by reason of conflict, natural disaster, the problems of poverty, public services quality and facilitate the task is urgent.

Discretion under normal circumstances it would be very useful in a wide range of government activity to fill the void the policy. Example innovation on bureaucratic activities, initiations arise as part of administrative reform. Many countries try to reform with some purpose. One of them raises a quality of public service. The fact, Ombudsman Republic of Indonesia reported, there were 2,853 reports or 41.59 percent, the public complained about public services in local government from a total of 6,859 reports nationally in 2015 (Ombudsman, 2016).

Several studies and scientific literature about policy discretion ever conducted and published. Young (2010) finding, the powers are given to it by the executive government makes for decision makers to promote the public interests or to advance their own interests by promoting more narrow special interests. Use of authority discretion contributes to highlight the decision very invisible where the government has the discretion (case of Utah). Beazer (2011) in his study revealed discretion done bigger bureaucrats into the activity of interpreting and applying the law, will experience a greater uncertainty about how the policies discretion are put into practice. Discretion contribute hinders investment, can create more uncertainty in some locations than elsewhere such as in Russia. Witt (2017) also found in New Zealand, discretion not only was 
Available Online at http://journal.unismuh.ac.id/index.php/otoritas

Otoritas : Jurnal Ilmu Pemerintahan, 8 (1), April, 2018, 19

the level of allowances allocated are associated with a position of the organization but is associated with individuals who occupy certain positions. The organization will also benefit from the knowledge that dissatisfaction of employees occurs due to restrictions use of discretion. Some of the published scientific literature also gives arguments that discretion policies will show power relationships (Howe, 2014). Policy discretion will increase the motivation of people, groups to do corruption (Kwon, 2014). Policy discretion is entrance criminal procedure (Chiao, 2016). Bottom line, there is information about policy discretion came to light, the evidence that is presented is generally not much different than the policies discretion is likely to lead decision to fill the void existing policy, the negative effects from general discretion, the abuse of authority and criminalization policies procedure.

Rigid rules, a bureaucracy that doesn't open up to change, the hierarchy of view, convoluted procedures, excessive political intervention and be one reason the bureaucracy is a very difficult practice of innovation. Therefore, the discretion became one way to shift the paradigm of innovation is hard to do in a bureaucratic activity, where the discretion is placed in a correct position to be instructions for the bureaucratic apparatus with ease to policy implementation. The focus of this research would like to explore further the public administrator dilemmas do policy discretion research to answer some questions. First, what causes the public administrator dilemmas to do policy discretion? and second Is there any relationship that can be dug between the discretion and the bureaucracy innovation initiation?

\section{RESEARCH METHODS}

This research article is classified as qualitative research, adopting a descriptive analysis based on secondary data and information sources. Meanwhile, a sys- tematic review was done to some general literature on discretion, decentralization, and bureaucracy innovation. Researchers combine and consider using an image, the relationships that effect to demonstrate the reality of reason can be inferred. It may just be a lot of factors that could be a related or most important factor included. This study will continue to evolve from other disciplines to continue in empirical research. Triangulation is used to draw conclusions with beware from a variety of data, literature, and documents from several discretion studies ever conducted and available on nationally and internationally. This process is continuous as the research progresses, even before the data is actually collected and analyze the collected data into data that systematic, orderly, structured and have to mean (Flick, 2009).

\section{RESULTS AND DISCUSSION}

History the appearance of discretion (discretionair, freies, discretion, ermessen) is freedom act of a person on the basic perception of his own thoughts. As the state of law, any action in government activities should be based on formal legality (Tamanaha, 2012; Dye, 2013; Prasojo, 2014; Davidson, 2017), however unlikely everything deeds provided for in government regulations. Therefore, in practice, the required freedom for holders of authorizations to perform each action. Discretion is not to translate a free authority for public administrators the intent and purpose discretion with the specific action for personal gain. Prasojo (2014) reveals the urgency of related administrative law is inseparable from inequality of legal material, the law emptiness, including laws governing the authority source attribution, delegation, and a mandate for public administrator authorities charged him with.

The concept of discretion got widespread attention in policy implementation literature (Hill \& Hupe, 2002; Tummers \& 
Available Online at http://journal.unismuh.ac.id/index.php/otoritas

Otoritas : Jurnal Ilmu Pemerintahan, 8 (1), April, 2018, 20

Bekkers, 2013). Policy discretion has a very important role to fill the void of policy by reflecting all aspects of nation and state. But the policy will tend to be problematic on the law when done and interpreted over the logic its own. In fact, discretion is so helpful when done properly and will benefit the citizen and the organization itself. For example, when a teacher teaching method curriculum that has been set by the government, in practice, the teacher could have been breaking the curriculum by the curriculum due to reasons not suitable to enhance the understanding process protege. Then a teacher would wear other methods such as applying the methods of teaching and learning with the CTL (contextual teaching and learning) that is not set in the policy aims only provide benefits for the student to achieve the target of curriculum It has been determined by the government in different ways. Another example, such a traffic police on duty in red lights, a traffic police will be able to breach the green light which means "the way" yet they lay off the pace, he will give a sign to motorists on the side lamp the red marked "stop" for speeding, the reason might be this police violation in order to parse congestion (Prasojo, 2014). This action does not violate the rules on certain conditions in public interest.

Rosenbloom, O'Leary, and Chanin (2010) confirm that discretion involves unconstrained or weakly constrained official action or inaction. Not only the various definitions that are known from a variety of literature but discretion has characteristics common to reaffirm the meaning, purpose and why discretion is done, general characteristics that in Table 1.

The general characteristics of Table 1 give an idea that discretion is not merely the authority is free to fill the void existing policy, but discretion can't be done without is based from a wide range of possible effects of positive and negative. The scope of discretion, requirements, and procedure for the use of discretion is also provided for in the Law of 30/2014 of Government Administration in Table 2.

Table 1. General Characterization of Discretion

Source: Elaborate by the author base on Goodin, Rein, \& Moran (2006); Rosenbloom, O'Leary, \& Chanin (2010); Mutereko \& Chitakunye (2015)

\begin{tabular}{lll}
\hline \multicolumn{1}{c}{ Characteristic } & Several Varietes & \multicolumn{1}{c}{ Advanced Literature } \\
\hline Positive characterization, "basic & - Strong discretion & Policy implementation; Pol- \\
level" & - Weak discretion & icy making process; Politi- \\
- Public administration involves ex- & - Formal discretion & cal theory; Policy analysis; \\
ecution of the law; & - Informal discre- & Administration and Law; \\
- An official can be said to have dis- & tion & Welfare state; and Public \\
cretion if he is given the power of & - Provisional discre- & policy. \\
doing discretion, judges in certain & tion & \\
circumstances to promote specific & - Ultimate discre- & \\
objectives; & tion &
\end{tabular}

- Some kinds of administration an official must make many decisions involving subtle and complex assessments of human characteristics. 
Available Online at http://journal.unismuh.ac.id/index.php/otoritas

Otoritas : Jurnal Ilmu Pemerintahan, 8 (1), April, 2018, 21

Further, in practice, public administrators can do discretion taking into account the capability of knowledge, the urgency to appraise and execute various types of discretion. Discretion will begin to occur when the administrator actions are informed values and or which conflicts interest with the system and the wider political effect. Discretion also the reason of public administrators conducting the policies implemented for benefit of the citizen (Rosenbloom, O'Leary, \& Chanin, 2010; Mutereko \& Chitakunye, 2015). For example, see the various bureaucratic pathology surely innovation becomes an objective to problem-solving of bureaucracy (Borins, 2008; Klimentova, 2014; Vries, Bekkers, \& Tummers, 2015). Presidential Regulation Number 80 of 2010 on Grand Design Bureaucracy
Reform 2010-2025 and Law of the Republic of Indonesia Number 23 of 2014 on Local Government as a legality requires the county to conduct various forms innovation considered to be able to improve activities performance, public services, and good governance. However, this form of innovation in policies implicitly submitted to the local government. Innovation in government activity does not have to go through such as research section a private sector (Vries, Bekkers, \& Tummers, 2015), but the bureaucratic apparatus is given the opportunity to explore their ability to bring up creative ideas (Yilmaz, Beris, \& Serrano-Berthet, 2008, 2010; Tummers \& Bekkers, 2013; Henderson, Țiclău, \& Balica, 2017). The proposition as it also occurs due to causality between a policy that is not set explicitly

Table 2. Scope, Rules, and Procedure of Discretion

Source: Law Republic of Indonesia Number 30 of 2014 on Government Administration

\begin{tabular}{|c|c|c|}
\hline Scope of Discretion & Rules of Discretion & Procedure of Discretion \\
\hline $\begin{array}{l}\text { - Decision making and/or ac- } \\
\text { tions based on conditions } \\
\text { the regulations provide an } \\
\text { option decisions and/or ac- } \\
\text { tions; } \\
\text { - Decision making and/or ac- } \\
\text { tion because the regulations } \\
\text { law does not regulate; } \\
\text { - Decision making and/or ac- } \\
\text { tion because the regulations } \\
\text { law is incomplete or unclear; } \\
\text { - Decision making and/or ac- } \\
\text { tion due to stagnation gov- } \\
\text { ernment to the broader in- } \\
\text { terests. }\end{array}$ & $\begin{array}{l}\text { - in accordance with the } \\
\text { purpose discretion; } \\
\text { - does not conflict with } \\
\text { the provisions of the } \\
\text { regulations law; } \\
\text { - in accordance with the } \\
\text { general principle of } \\
\text { good governance; } \\
\text { - based on objective rea- } \\
\text { sons; } \\
\text { - does not pose a conflict } \\
\text { of interest; } \\
\text { - done with goodwill. }\end{array}$ & $\begin{array}{l}\text { - Officials using discretion } \\
\text { are required to describe } \\
\text { the purpose, substance, } \\
\text { and impact of } \\
\text { administration and state } \\
\text { finances; } \\
\text { - Officials use discretion } \\
\text { must submit a written } \\
\text { approval request to the } \\
\text { supervisor official; } \\
\text { - Within } 5 \text { (five) working } \\
\text { days after the application } \\
\text { file is received, the } \\
\text { supervisor official sets } \\
\text { approval, repair } \\
\text { instructions, or refusal; } \\
\text { - If the supervisor official } \\
\text { makes a rejection, the } \\
\text { supervisor official must } \\
\text { provide the reasons for the } \\
\text { denial in writing. }\end{array}$ \\
\hline
\end{tabular}


Available Online at http://journal.unismuh.ac.id/index.php/otoritas

Otoritas : Jurnal Ilmu Pemerintahan, 8 (1), April, 2018, 22

and urgency.

Furthermore, this section of findings and discussion will also outline the linkages between discretion and decentralization, discretion and bureaucracy innovation, as well as the public administrator dilemmas when they decide to use discretion. This can enrich our insight, providing little argumentation so that in local government activities whether policy discretion required.

\section{Discretion Related to Decentralization}

In almost all democratic and liberal countries write down in its constitution recognition of local government (Constitutional and Legal Status). Local government arrangements not only as constitution recognition but rather to the recognition of local government as part a comprehensive government system. For example, decentralization model is not an option that actually can be fully applied to the area of "certain" such as Aceh and Papua province, transfer of power will not be enough to resolve the problems that exist in Aceh and Papua province, other necessary steps such as cultural and religious culture approach. The existence a mismatch the directions of development that are often out of sync with interests of a particular region and condition that caused marginalization of economics incidence (Bowman \& Kearney, 2011; Pepinsky \& Wihardja, 2011; Holzhacker, Wittek, \& Woltjer, 2016).

As for heavy point implementation of decentralization is emphasized in some basic considerations, political dimension,

Table 3. Factor Affecting Local Administrative Discretion

Source: Yilmaz, Beris, and Serrano-Berthet $(2008,2010)$

\begin{tabular}{ll}
\hline \multicolumn{1}{c}{ Factor Affecting } & \multicolumn{1}{c}{ Core Argument } \\
\hline $\begin{array}{l}\text { Ability of Regulate } \\
\begin{array}{l}\text { Discretion to Procure and Administer Ser- } \\
\text { vices }\end{array}\end{array}$ & $\begin{array}{l}\text { Derivate policy } \\
\text { Flexibility of policies for how that is the new } \\
\text { ways, high knowledge of bureaucratic } \\
\text { apparatus } \\
\text { Discretion over Civil Service and Employ- } \\
\text { Competence, budgetary transparency, salary } \\
\text { system for the bureaucratic apparatus }\end{array}$ \\
\hline
\end{tabular}

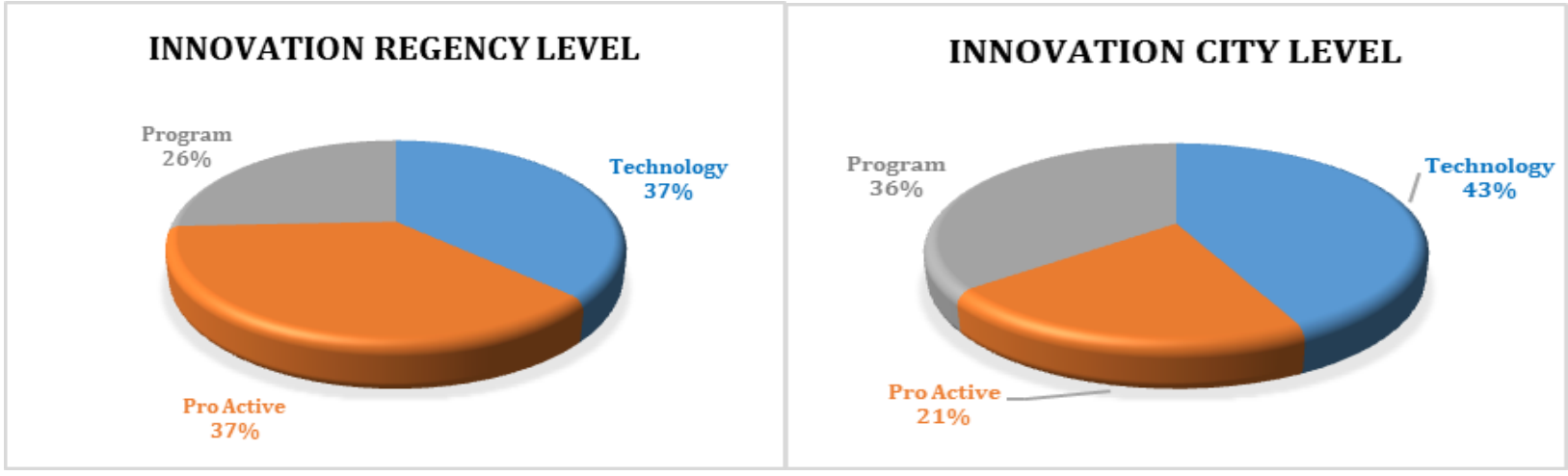

Figure 1. Innovation Regency and City Level

Source: Regulation Minister of Administrative and Bureaucratic Reform Number 20 of 2017 on Determination Top 99 Public Service Innovations of 2017 
administrative, governance and good public services relative to can be more effective (Bannink \& Ossewaarde, 2012; Kwon, 2014; Kim \& Yoon, 2017). Decentralization, in particular, brings some benefits, on the other hand, decentralization is not fully realized to offer and increase the government accountability. And decentralization is also used as a tool of reform in various areas of government activity (Neudorfer \& Neudorfer, 2014; Smokes, 2015; Hulst, Mafuru, \& Mpenzi, 2015). Many kinds of literature are found where decentralization does not cause accountability of government activity significantly (Yilmaz, Beris, \& Serrano-Berthet, 2008).

Description relationship between discretion and decentralization (accountability) has never been revealed by Yilmaz, Beris, and Serrano-Berthet $(2008,2010)$. They analyze the strong relationship between discretion and accountability of local government will encourage good governance. However, discretion does not mean doing something contrary to rules and norms of public interest. Discretion is done not on basis of its own authority, but discretion is done as a rapid form of response and responsibility toward a variety problem solving that is not set in the policy of the government.

Yilmaz, Beris, and Serrano-Berthet $(2008,2010)$ provide an explanation factors that may affect the incidence of discretion, as shown in Table 3.

As part its administrative autonomy, local governments require a set of strengths and capacity on issues that affect their jurisdiction (Cheema \& Rondinelli, 2007; Grindle, 2007; Dubois \& Fattore, 2009; Bowman \& Kearney, 2011; Kwon, 2013; Holzhacker, Wittek, \& Woltjer, 2016). They need authority to approve or reject the policy. Local governments also need tools such as the power to give sanction and punish noncompliance. This increases the discretionary authority to make decisions and take action regarding who can benefit from resources or opportunities provided. Discretion committed to some conditions which are urgent, in the government activity required to further enhance public trust in government. Local level policies have needed to translate goals and purpose over a higher regulation (Yilmaz, Beris, \& Serrano-Berthet, 2008, 2010; Wood, 2011).

Mandate and responsibilities expanded to new services require that local governments do a policy discretion. This, in turn, requires flexibility in legislation, policy and bureaucratic apparatus of high quality. Therefore, local governments can develop ways that are considered able and easy to implement. Discretion understood by some public administrators as an attempt to seek the opportunity of doing unlawful acts (Cox III, Hill, \& Pyakuryal, 2008; Yilmaz, Beris, \& Serrano-Berthet, 2008, 2010; Wangrow, Schepker, \& Barker III, 2015).

Public administrator dilemmas to do a discretion greater than not do it at all. A difficult situation requires people to make choices between two possibilities. One side of government policies should be implemented with as best they can, but the others in terms of legislation that provide choice, not regulate, incomplete or unclear, and/or the presence of stagnation of government becomes the driving factor it does discretion for the benefit of public and organizations. There are some things that might happen why public administrators are very careful to do discretion. First, discretion close to criminalization policy procedures would open the chance of administrative crimes, corruption, collusion, and nepotism and tends to legalize relations of power. Second, the level of public knowledge of the administrator capabilities are low, and the placement of public administrator that is not based on the expertise will be an issue when interpreting discretion. Third, discretion is often done without regard to objective rea- 
Available Online at http://journal.unismuh.ac.id/index.php/otoritas

Otoritas : Jurnal Ilmu Pemerintahan, 8 (1), April, 2018, 24

sons why discretion became an option and may give rise to a conflict of interest. Fourth, the use of discretion close to change the allocation usage of the budget, and last policy unlawfully may be extremely difficult to review. In some cases, the administrator may appear to be above the law or beyond the limit because they are unable to explain their actions (Cox III, Hill, \& Pyakuryal, 2008; Yilmaz, Beris, \& Serrano-Berthet, 2008, 2010; Rosenbloom, O'Leary, \& Chanin, 2010; Prasojo, 2014; Chiao, 2016; Witt, 2017).

\section{Discretion Versus Bureaucracy Innova- tion}

The Law Republic of Indonesia Number 30/2014 on Government Administration allows officials to use policy discretion in decision-making. Discretion should be translated by those who have knowledge and capacity to do. The public administration needs to recognize the discretion has to offer, this situation will limitations recognize upon discretion created by their own thoughts. At the most basic level we can see that with unbiased interpretation, discretion will look like a view of optimistic and pessimistic it will be different. Mindset differently comes from experience, this assumption will raise the perspective of personality and describe an official is still very necessary to do a policy discretion.

Although the experts and practitioners describe no profiles of public administrators (leadership) is ideal. This is important because it will shape the perception of public administrator about discretion available, discretion is not a good will bring them on legal affairs because of abuse authority through reflective practice. Ireland for example, applying the power discretion with maximum effectiveness, great efforts are being made to do discretion it through the formation of a "think tank" policies, and a special group involving the social partners, academics to recommend policy initiatives. In organ- izations, discretion aims to build culture, policies, routines, standards, and processes are different or contrary to the normal situation (Galavan, Murray, \& Markides, 2008).

The link between innovation and information discretion indeed never be published. Henderson, Țiclău, and Balica (2017) noted the policy will allow discretion to perform more activities innovation. There is a chance happening that discretion can support innovation activities, or even innovations become a tool used to make abuse of power through the discretion. There is a contradictory public administrator perception to conduct innovation, innovation always is perceived using sophisticated technology that will use a lot of the state finance, the basic definition of innovation is not like that.

Data initiation of innovation at the local government level (regency/city) of 416 regencies, a city of 98 in Indonesia can be traced from the determination of the top 99 public service innovations contained in the decision from Regulation Minister of Administrative and Bureaucratic Reform Republic of Indonesia assignment public service Innovations of 2017. Public innovation model done can be seen in the pictures the following figure 1.

There are differences in use of forms innovation between the level of regency and cities in Indonesia. For example, the utilization of technology in innovation at the city level (43 percent) higher than at the level of regency (37 percent). This gives indications that utilization technologies that are evenly distributed among regions may not be so useful due to various constraints. Constraints that might be caused lack of government budget to allocate expensive technology-based innovation. Culture and local wisdom, different knowledge levels, the urgent necessity, and urgency can affect usage model of innovation (Patel \& Patel, 2008; Kaasa \& Vadi, 2010; Piening, 2011; McLaughlin \& 
Kennedy, 2016). Another example is on the level of regency form innovation activities using proactive (37 percent) more possible to use, in general, an existing citizen in the Regency still upholding local wisdom. So innovation activity more proactive government efforts to attempt to directly interact with the citizen with public awareness, guidance, and real action.

Many innovations to use and exploit information technology (web, smartphone) reason these models are believed to be more efforts to facilitate the administrative procedures ultimately uphold the principles of good governance. Not just a model of what used to innovate, but the "shape" of innovations that are regulated in government. When not set required discretion to set it. There is a requirement to be met, if the discretion wants to do of which outlines the intent, purpose, substance, and impact of administration, potentially changing the state finance, discretion is done based on the state of emergency, state of urgent, and/ or natural disaster occur. Outlining the intent, purpose and need substance special skills of public administrator.

Therefore, not all officials are fond doing policy discretion (Goodin, Rein, \& Moran, 2006). Need to be careful to do it, basically, innovation is the urgent need to provide public service, and as an attempt to restore the public's trust in government. Innovation also needs a budget that does little (Alberti \& Bertucci, 2007; Valkama, Bailey, \& Anttiroiko, 2013; Torfing \& Triantafillou, 2016). Innovation describes an idea, or object that is considered new. At least 60 have an innovation definition has been universally manifested themselves in various disciplines, and innovation can relate to the idea, service, process, technology, and organization (Baregheh, Rowley, \& Sambrook, 2009).

There are several things that can be observed the decision makers prior to policy discretion. First, discretion is not contrary to the rules, whether the activity can influence the government, financial, and norms propriety of the public interest.

Second, discretion is supposed to be translated by a person who has a high capability or creation of a team framers discretion to give a response to the decision makers prior to discretion. Third, the basic urged to common interests as the norm. Fourth, discretion should abolish interest relations of power and the criminalization procedure. And obey all regulations that have been set up on policy discretion.

\section{Dilemmas Bureaucracy Innovation}

For bureaucracy, innovation is considered not so required (Goodsell, 2015). But in the state reform, bureaucratic innovation must always be evolving towards improvement. The gains in may are relative, the extent to which innovation in deem fit in with existing value, an idea that does not match the values that are prevalent and contrary to social norms will never adopt (Caiden, 2009; Ho, 2011; Kim \& Han, 2014). The theory that explains the context of the contingency of bureaucracy and innovation do exist, but limited to just one contingency variables effect. The relative effects contingency factors are different, or the simultaneous effect of contingency factors. The new model should be included in the contingency factor combinations and dimensions of innovation. For example, the effect of innovation characteristics should be elaborated specifically between groups organizations of various types or a different size (Styhre, 2007; Anttiroiko, Bailey, \& Valkama, 2011; Torfing \& Triantafillou, 2016).

In practice, initiation of innovation activity in bureaucracy is often utilized by the public administrator to excuse acts of corruption (DiRienzo \& Das, 2014; Mantzaris, 2016; Ledeneva, Bratu, \& Köker, 2017). However, the empirical relation- 
Available Online at http://journal.unismuh.ac.id/index.php/otoritas

Otoritas : Jurnal Ilmu Pemerintahan, 8 (1), April, 2018, 26

ship between corruption and innovation is still not so much explored (Mahagaonkar, 2008). This situation arose due absence of government policies that are explicitly set on a wide variety of shapes, a form of innovation. The complexity of context and characteristics such a level of economic development, political history, institutional heritage, ethnic and country social-culture are often overlooked in policy DiRienzo \& Das, 2014; Ledeneva, Bratu, \& Köker, 2017). In some discretion, the condition will contribute to legalize the law abuse of power. The reason is that the policy void, this condition be open opportunities between the parties will take advantage.

On the other hand, the urgency of forcing the public administrator to take administrative action against implicates might be illegal. Therefore, the activity of bureaucracy is often regarded by the public as bad government organizations in providing public services. The absence policy context set explicitly are often made between action and was puzzled as the urgent need to innovate in an effort to improve the quality of public service. For the country which governs the use of discretion through a set of regulations will be easier to do since discretion is not something illegal in government policy. But discretion must be supported with a deeper complex understanding including the application of public service ethics and transparency requirements (Cox III, Hill, \& Pyakuryal, 2008; Keeler, 2013).

\section{CONCLUSION}

In a study of policy, discretion occupies a space of its own because of discretion existing policy outside the formal rules. Fill in the blanks on policy as a legal basis in government activity, nature of urgent, public interest be some reasons why discretion is done. Bureaucracy innovation for example, is considered an urgent requirement when the policy is not set explicitly on this early innovation from public administrator dilemmas to act. Claims of poor public services by the bureaucracy became terms why action is needed to resolve them immediately.

However, the use discretion it is not easy to do, there are negative consequences that must be accepted as violating procedures, the legality of the law if policy discretion translated into bias. More discretion used as a motivational tool to legalized abuse of authority and power that is closer to corruption, collusion, and nepotism. The use of relation of power is also the cause discretion is considered something negative when it's done. Positively, discretion can contribute to legalize a way deemed urgent for the public interest, it does not violate the existing rules.

The recommendations can be proposed through this research articles for the public administrator is discretion, not something considered an activity that violates the law, but discretion is just the way that can be taken to address the ambiguity of policy is there to bring up creativity, adoption of a new way which does not conflict with the existing regulations. For other researchers, in order to reveal the other side of discretion from the view of public administration or from the view of other scientific, so the dilemmas of doing discretion can bring the right solution for public administrators.

foreseen for the non-compliants, making possible informal renegotiation of policies at the local level. Further studies are needed before being able to lay out a theory of informal governance. However, I would suggest, this combination of elastic rules and limited control is allowing local leaders and actors to feel relatively free and making easier to accept a Ukrainian identity based on relatively flexible boundaries and markers. 
Available Online at http://journal.unismuh.ac.id/index.php/otoritas

Otoritas : Jurnal Ilmu Pemerintahan, 8 (1), April, 2018, 27

\section{ACKNOWLEDGEMENT}

I would like to express my gratitude to my colleagues in the Department of Public Administration of the Faculty of Social and Political Sciences of Universitas Padjadjaran, Indonesia.

\section{REFERENCES}

Alberti, A., \& Bertucci, G. (2007). Innovation in Governance and Public Administration: Key Issues and Perspectives. In D. o. Affairs, Innovations in Governance in the Middle East, North Africa, and Western Balkans: Making Governments Work Better in the Mediterranean Region (pp. 3-12). New York: United Nations.

Amrizal, Rani, F., Ginting, B., \& Tarigan, P. (2015).

Asymmetric

Decentralization Aceh; Governor Consultation and Consideration Context on Central Government Administrative Policy. Journal of Humanities And Social Science, 20 (9), 01-10. doi:10.9790/083720950110

Anttiroiko, A.-V., Bailey, S. J., \& Valkama, P. (2011). Innovations in Public Governance in the Western World. Amsterdam: IOS Press BV.

Bannink, D., \& Ossewaarde, R. (2012). Decentralization: New Modes of Governance and Administrative Responsibility. Administration \& Society, 44(5), $595-624$. doi:10.1177/0095399711419096

Baregheh, A., Rowley, J., \& Sambrook, S. (2009). Towards a Multidisciplinary Definition of
Innovation. Management Decision, 47(8), 1323-1339. doi:10.1108/0025174091098457 8

Beazer, Q. H. (2011). Risk in Regions: Bureaucratic Discretion, Regulatory Uncertainty, and Private Investment in the Russian Federation. Requirements for the Degree Doctor of Philosophy, The Ohio State University, Ohio.

Borins, S. (2008). Research on Innovations in Government: What Next? In S. Borins, Innovations in Government: Research, Recognition, and Replication (pp. 199-205). Washington D.C: Brookings Institution Press.

Bowman, A., \& Kearney, R. (2011). State and Local Government (8th ed.). Boston: Cangange Learning.

Caiden, G. E. (2009). Administrative Reform. Chicago: Aldine Transaction.

Cheema, G. S., \& Rondinelli, D. A. (2007). Decentralizing

Governance: Emerging Concept and Practice. Washington D.C: Brookings Institution Press.

Chiao, V. (2016). Discretion and Domination in Criminal Procedure: Reflections on Pettit. Politics, Philosophy \& Economics, 15(1), 92110. doi:10.1177/1470594X15599104

Cox III, R. W., Hill, M. L., \& Pyakuryal, S. (2008). Tacit Knowledge and Discretionary Judgement. Public Integrity, 10(2), 151-164. 
Available Online at http://journal.unismuh.ac.id/index.php/otoritas

Otoritas : Jurnal Ilmu Pemerintahan, 8 (1), April, 2018, 28

doi:10.2753/PIN1099-

9922100204

Davidson, N. M. (2017). Localist Administrative Law. The Yale Law Journal, 126(3), 564-634.

DiRienzo, C., \& Das, J. (2014). Innovation and Role of Corruption and Diversity: A Cross-Country Study. International Journal of Cross Cultural Management, 15(1), 5172.

doi:10.1177/1470595814554790

Dubois, H. F., \& Fattore, G. (2009). Definitions and Typologies in Public Administration Research: The Case of Decentralization. International Journal of Public Administration, 32(8), 704-727. doi:10.1080/0190069090290876 0

Dye, T. R. (2013). Understanding Public Policy (14th ed.). Upper Saddle River, NJ: Pearson Education.

Flick, U. (2009). An Introduction to Qualitative Research (4th ed.). London: SAGE Publications.

Galavan, R., Murray, J., \& Markides, C. (2008). Strategy, Innovation, and Change: Challenges for Management. New York: Oxford University Press .

Goodin, R. E., Rein, M., \& Moran, M. (2006). The Public and its Policies. In M. Moran, M. Rein, \& R. E. Goodin, The Oxford Handbook of Public Policy (pp. 3-38). New York: Oxford University Press .

Goodsell, C. T. (2015). New Case
Bureaucracy. Washington, DC: CQ Press.

Grindle, M. S. (2007). Going Local Decentralization, Democratization, and the Promise of Good Governance. New Jersey: Princeton University Press.

Henderson, A., Țiclău, T., \& Balica, D. (2017). Perceptions of Discretion in Street-Level Public Service: Examining Administrative Governance in Romania. Public Performance \& Management Review, 1-28. doi:10.1080/15309576.2017.1400 987

Hill, M., \& Hupe, P. (2002). Implementing Public Policy: Governance in Theory and in Practice. London: SAGE Publications.

Ho, K. L. (2011). Reinventing the Bureaucracy? Malaysia's New Administrative Reform Initiatives. Journal of Comparative Asian Development, 1(1), 87-104. doi:10.1080/15339114.2002.9678 351

Holzhacker, R. L., Wittek, R., \& Woltjer, J. (2016). Decentralization and Governance in Indonesia. Switzerland: Springer International Publishing AG.

Howe, L. E. (2014). Administrative Law and Governmentality: Politics and Discretion in a Changing State of Sovereignty. Administrative Theory \& Praxis, 24(1), 55-80. doi:10.1080/10841806.2002.1102 9340 
Available Online at http://journal.unismuh.ac.id/index.php/otoritas

Otoritas : Jurnal Ilmu Pemerintahan, 8 (1), April, 2018, 29

Hulst, R., Mafuru, W., \& Mpenzi, D. (2015). Fifteen Years After Decentralization by Devolution: Political-Administrative Relations in Tanzanian Local Government. Public Administration Development, 35(5), 360-371. doi:10.1002/ pad.1743

Kaasa, A., \& Vadi, M. (2010). How Does Culture Contribute to Innovation? Evidence from European Countries. Economics of Innovation and New Technology, 19(7), 583604.

doi:10.1080/1043859090298722 2

Keeler, R. L. (2013). Managing Outsourced Administrative Discretion. State and Local Government Review, 45 (3), 183-188. doi:10.1177/0160323X13496108

Kim, D.-R., \& Yoon, J.-H. (2017). Decentralization, Government Capacity, and Environmental Policy Performance: A Cross National Analysis. International Journal of Public Administration, 111.

doi:10.1080/01900692.2017.1318 917

Kim, S., \& Han, C. (2014). Administrative Reform in South Korea: New Public Management and the Bureaucracy. International Review of Administrative Science, o(0), 1-19. doi:10.1177/0020852314558034

Klimentova, S. (2014). Innovation in the Public Sector: Is it Measurable. Studies in Managerial and Financial
Accounting, 28,

289-315 doi:10.1108/S1479351220140000028021

Kwon, I. (2014). Motivation, Discretion, and Corruption. Journal of Public Administration Research and Theory, 24(3), 765-794. doi:10.1093/jopart/mus062

Law Republic of Indonesia Number 23 of 2014 on Local Government.

Law Republic of Indonesia Number 30 of 2014 on Government Administration.

Ledeneva, A., Bratu, R., \& Köker, P. (2017). Corruption Studies for the TwentyFirst Century: Paradigm Shifts and Innovative Approaches. The Slavonic and East European Review, 95(1), 1-20. doi:10.5699/ slaveasteurorev2.95.1.0001

Mahagaonkar, P. (2008). Corruption and innovation: A Grease or Sand Relationship? Retrieved from Jena Economic Research Papers, \#2008 -017: http://www.econbiz.de/ archiv1/2009/63495_grease_sand _relationship.pdf

Mantzaris, E. (2016). Innovative Leadership Against Corruption in the Public Sector: The Case for South Africa. African Journal of Public Affairs, 9(1), 59-69.

McLaughlin, G. C., \& Kennedy, W. R. (2016). A Guide to Innovation Processes and Solutions for Government. Boca Raton, FL: CRC Press.

Mutereko, S., \& Chitakunye, P. (2015). Discretion and Autonomy: Public 
Available Online at http://journal.unismuh.ac.id/index.php/otoritas

Otoritas : Jurnal Ilmu Pemerintahan, 8 (1), April, 2018, 30

Administrators' Dilemmas in the Implementation of National Curriculum Statements. International Journal of Public Administration, 38(2), 143-155. doi:10.1080/01900692.2014.9348 35

Neudorfer, B., \& Neudorfer, N. S. (2014). Decentralization and Political Corruption: Disaggregating Regional Authority. Publius:The Journal of Federalism, 45(1), 24-50. doi:1093/publius/pju035

Ombudsman. (2016). Laporan Tahunan 2015. Jakarta: Ombudsman Republik Indonesia.

Patel, T., \& Patel, C. (2008). Learning Cultures for Sustained Innovation Success. Innovation: The European Journal of Social Science Research, 21(3), 233-251. doi:10.1080/1351161080240491 4

Parry, R. (2008). Changing UK Governance Under Devolution. Public Policy and Administration, 23(1), 114-120. doi:10.1177/0952076707083290

Pepinsky, T. B., \& Wihardja, M. M. (2011). Decentralization and Economic Performance in Indonesia. Journal of East Asian Studies, 11(3), 337371. doi:10.1017/

S1598240800007372

Piening, E. P. (2011). Insights into the Process Dynamics of Innovation Implementation. Public Management Review, 13(1), 127157. doi:10.1080/14719037.2010.5016 15

Prasojo, E. (2014, Oktober 07). Diskresi Bukan Berarti Kewenangan Bebas. Retrieved from Kementrian Pendayagunaan Aparatur Negara dan Reformasi Birokrasi: https:// www.menpan.go.id/site/beritaterkini/2650-diskresi-bukanberarti-kewenangan-bebas

Presidential Regulation Number 80 of 2010 on Grand Design of bureaucratic reform 2010-2025.

Regulation Minister of Administrative and Bureaucratic Reform Number 20 of 2017 on Determination Top 99 Public Service Innovations of 2017.

Rosenbloom, D. H., O'Leary, R., \& Chanin, J. (2010). Public Administration and Law (3rd ed.). Boca Raton, FL: CRC Press.

Sahaym, A., Trevino, L. J., \& Steensma, H. K. (2012). The Influence of Managerial Discretion, Innovation, and Uncertainty on Export Intensity: A Real Options Perspective. International Business Review, 21(6), 1131-1147. doi:10.1016/j.ibusrev.2012.01.003 Smokes, P. (2015). Rethinking Decentralization: Assessing Challenges to a Popular Public Sector Reform. Public Administration Development, 35(2), 97-112. doi:10.1002/pad.1703

Styhre, A. (2007). The Innovative Bureaucracy: Bureaucracy in an of Fluidity. New York: Routledge.

Tamanaha, B. Z. (2012). The History ans 
Available Online at http://journal.unismuh.ac.id/index.php/otoritas

Otoritas : Jurnal Ilmu Pemerintahan, 8 (1), April, 2018, 31

Element of Rule of Law. Singapore journal of Legal Studies, 232-247.

Tarlton, C. D. (1965). Symmetry and Asymmetry as Elements of Federalism: A Theoretical Speculation. The Journal of Politics, 27(4), 861-874. Retrieved from http://www.jstor.org/ stable/2128123.

Torfing, J., \& Triantafillou, P. (2016). Enhancing Public Innovation by Transforming Public Governance. Cambridge: Cambridge University Press.

Tummers, L., \& Bekkers, V. (2013). Policy Implementation, Street Level Bureaucracy, and the Importance of Discretion. Public Management Review, 16(4), 527-547. doi:10.1080/14719037.2013.8419 78

Valkama, P., Bailey, S. J., \& Anttiroiko, A.-V. (2013). Organizational Innovation in Public Services: Form and Governance (1st ed.). Hampshire: Palgrave Macmillan.

Vries, H. d., Bekkers, V., \& Tummers, L. (2015). Innovation in the Public Sector: A Systematics Review and Future Research Agenda. Public Administration, 94(1), 146-166. doi:10.1111/padm.12209

Wangrow, D. B., Schepker, D. J., \& Barker III, V. L. (2015). Managerial Discretion: An Empirical Review and Focus on Future Research Directions. Journal of Management, 41(1), 99-135.
Witt, M. D. (2017). Discretion in Decision Making: The Fonterra Case. Requirements for the Degree of Doctor of Philosophy , The University of Waikato, Hamilton.

Wood, C. (2011). Understanding the Consequences of Municipal Discretion. The American Review of Public Administration, 41(4), 411427.

doi:10.1177/0275074010381111

Yilmaz, S., Beris, Y., \& Serrano-Berthet, R. (2008). Local Government Discretion and Accountability: A Diagnostic Framework for Local Governance. Washington, D.C: The World Bank.

Yilmaz, S., Beris, Y., \& Serrano-Berthet, R. (2010). Linking Local Government Discretion and Accountability in Decentralisation. Development Policy Review, 28(3), 259-293. doi:10.1111/j.14677679.2010.00484.x

Young, T. E. (2010). How Government Officials With Discretion Make Decisions: Case Study of Tax Law. A Dissertation Submitted Doctor of Philosophy, University of Utah, Utah. 